\title{
COL1A2 wt Allele
}

National Cancer Institute

\section{Source}

National Cancer Institute. COL1A2 wt Allele. NCI Thesaurus. Code C52480.

Human COL1A2 wild-type allele is located in the vicinity of 7q22.1 and is approximately 37 $\mathrm{kb}$ in length. This allele, which encodes collagen alpha-2 (I) chain protein, plays a role in the structural integrity of tendons, ligaments and bones. Mutations in the gene are associated with atypical Marfan syndrome, Ehlers-Danlos syndrome types and osteogenesis imperfecta types. 